\title{
Research on the Effects of Influencing Factors of International Students on Employability: A Case Study in China
}

\author{
Kalissa Fatoumata Kir ${ }^{1}$, Francis Atta Sarpong', Yakubu Yari Kate Dazagbyilo', Manli Boukari² \\ ${ }^{1}$ School of Economics and Management, Anhui University of Science and Technology, Huainan, China \\ ${ }^{2}$ School of Civil Engineering, Anhui University of Science and Technology, Huainan, China \\ Email: *nanaipee@gmail.com
}

How to cite this paper: Kir, K. F., Sarpong, F. A., Dazagbyilo, Y. Y. K., \& Boukari, M. (2021). Research on the Effects of Influencing Factors of International Students on Employability: A Case Study in China. Open Journal of Business and Management, 9, 1942-1964.

https://doi.org/10.4236/ojbm.2021.94105

Received: June 25, 2021

Accepted: July 25, 2021

Published: July 28, 2021

Copyright $\odot 2021$ by author(s) and Scientific Research Publishing Inc. This work is licensed under the Creative Commons Attribution International License (CC BY 4.0).

http://creativecommons.org/licenses/by/4.0/ (c) (i) Open Access

\begin{abstract}
The current study explored the effects of international students' influencing factors on their perceived employability: A case study of China. The explanatory research design was adopted to involve 514 international African students in the study. The research was conducted with a random sampling technique. Fifty (50)-test items standardized questionnaire was adopted as research instrument for the study. Using Structural Equation Modeling (SEM), the study found that there is a strong positive relationship between students' personal professional ability, university curriculum and social support, interpersonal and communication ability, social support and perceived employability. Four hypotheses were tested to determine whether they could predict international African students' perceived employability. Out of the four models, it was revealed that personal professional ability, university curriculum and social support, interpersonal and communication ability, social support significantly predicted international students' employability. The study found that the aforesaid variables have a significant positive effect on students' perceived employability and that an increase in any of the influencing factors would significantly and positively increase international African students' chances of employability after graduating from their respective universities in China. The study concluded that international African students could secure themselves employment after school within China or outside China if they take serious consideration of developing their personal professional abilities, interpersonal communication skills, social support from family and loved ones and become committed to the courses they are offered and taught in their respective university with uttermost precision and importance.
\end{abstract}

\section{Keywords}

Graduate Employability, Personal Professional Ability, University 
Curriculum and Social Support, Interpersonal and Communication Ability, SEM

\section{Introduction}

Like any other developed or developing country, China has been amassed by unclear fluctuations brought by globalization on education and employment. In this global era, higher education has focused on developing graduates who can be well equipped and effectively contribute to society (Abas \& Imam, 2016). One of the essential proxy measures of the purpose of higher education is the ability to ensure graduate employability. Employability is a critical concern for employers and universities (Donald, Baruch, \& Ashleigh, 2019). Over the past decade, graduate students' employment has subjugated much economic and educational policy and research into investigating postgraduate students' careers after completing their school (Lindberg, 2007; Mason, Williams, \& Crammer, 2009). The subject of employability has garnered many universities in the UK, USA, and other developing countries in integrating work-related learning courses in the degrees conferred to graduate students with the motive of improving their employment overlook (Holmes, 2013). Wilton (2008) asserts, "the factor of graduate employability assesses the relationships that exist between the skills obtained by graduates and how they can use those skills for acquiring the job."

Globalization has deepened the movement of students from their country of origin to foreign countries to study. There has been an increment in undergraduate, postgraduate, and postdoctoral, foreign international students in Chinese Universities over the past decade. Despite the increment in the number of students studying in Chinese there seems, to be no literature available on their employability and competences in the job competencies school (Ngwira, Mapoma, Hong, Sariyo, \& Kondowe, 2015). The Ministry of Education of China in the years 2016 revealed that there is sharp increase in the quantities of international students enrolling in Chinese Universities since the country started open-door policy in 1978 (Guo \& Guo, 2016). The Ministry of education in the year 2020 revealed that total number of international students in the year 2013 had reached over 492,185 and was expected to reach over 500,000 international students by the year 2020. Research on postgraduate employment revealed that higher education institutions had played a significant role in graduates' employability skills (Fallows \& Steven, 2000). However, there appears to be contentions in the literature on how courses taught in schools help graduates seek a job after school and even be successful in those works. Some stakeholders on employability have buttressed that most graduate students lack generic skills (Green, 2003; Yorke, 2004).

There appears to be few current empirical studies exploring international students' employability and competence in countries such as China, India, South 
Africa, and many more (Tomlinson, 2007). Existing literature mainly focused on international students' employability in developed countries such as the UK, USA, Germany, etc. (King, Findlay, Ahrens \& Dunne, 2011). Higher education, specifically graduate studies, focuses on developing the capabilities (knowledge, skills, and attitudes) of graduates to the highest level of competence so that they could effectively contribute their quota to national development (Abas-Mastura et al., 2013). The success of graduates at the workplace can be measured by their ability to expertly put on the skills, knowledge, and principles acquired in school to match the requirements of their job specification and gratify employers' demands by contributing to achieving the predetermined goal of the organization. In the African setting, there appears to be a rise in the number of students who have acquired their higher education in China. The countries with the most students were Ghana (5552), Nigeria (4746), and Tanzania (3520). However, despite the numerous numbers of students who travel each and every day, the impact of the education on their employability is a grey area that demands further investigation (China Power Team, 2017). The aforesaid can only be done when there is a match between the employability and competence of postgraduate international students within china and the skills acquired. There has been increasing of studies on foreign students and higher education and its relationship with employability. Many of such studies have been conducted in the US, Europe, Russia, Japan South Korea and many more but there seems to be scanty research work in China and especially concentrating of African students (Camiciottoli, 2010, Dams \& Pagola, 2007; David-West \& Choi, 2010; Dorozhkin, \& Mazitova, 2008; Sciolla, Ziajko, \& Salguero, 2010). For the above studies, it failed to consider the factors that influences those study and how the demography feature determines student's employability, hence the need for a study into such phenomenon. Therefore, this paper seeks to investigate the perceived employability and influencing factors of international students, A case study in China. The remaining paragraphs explain in detail review of related studies, research methodology adopted for the study, discusses results and summarize and conclude the study.

\section{Literature Review}

\section{Existing Literature on Graduates Employability and Influencing Factors}

The term employability can be defined the one's possession of abilities, capabilities, knowledge and skills to identify a job, remain on existed job or seek for new employment (Rothwell and Arnold, 2007). Thijssen et al. (2008) and Fugate et al. (2004) opined that employability can be further defined as psycho-social paradigm epitomizing a set of individual features that promote appropriate behaviors needed to support capacity to develop within continuously evolving employment environments. Employability can be viewed as part of the labor market which consist of demand and supply of labor (Forrier \& Sels, 2003). Over the last dec- 
ade, the employment prospects of university international graduates have driven most educational and economic policy of countries (Mason, Williams, \& Cranmer, 2009) and several researchers such as (Shafie \& Nayan, 2010) have become increasingly interested in how international students' knowledge acquired through international education help them to secure jobs within and outside their country of study and country of origin (Lindberg, 2007). A review of literature on the employability of international graduates' reveals that there' seems to be very little current research work investigating how graduate are seeking employment after school and how some influencing factors determines their employability within their country of origin and place of study in the light of higher education especially for African students (Tomlinson, 2007). In addition, literature on the current international graduate's employability in general has a clear "national" emphasis in the United Kingdom or the United States, and other developed and developing countries with very little mention of the progressively foreign aspects of international students' employability, not to mention countries like China (Waters, 2009; King, Findlay, \& Ahrens, 2010).

Employability skills are described as generic and non-technical skills and knowledge required for performing effectively and efficiently on kinds of jobs (Ju, Zhang, \& Pacha, 2012), and have been acknowledged as one of the most important skills in the modern global work environment. Several Colleges and Universities in the developed countries are now offering work-integrated learning programs as part of their degrees in order to improve international graduate job prospects. This viewpoint is often focused on the assumption that universities can (and should) produce international graduates who are fully prepared and ready for work (Holmes, 2013). The mastery of competencies required in the employment market is dependent on existing mastery of competencies desirable for the dynamic employment climate. It is well understood that higher education is primarily responsible for arranging eligible international with the provision of the necessary attitudes, information, skills and knowledge for success at the work environment after graduation. This is in line with the research done by Graduate Employability Skills Report in the year 2007 that it is the responsibilities of many universities to produce graduates especially international students with highly desirable features and skills that are to the country's success and economic wealth.

There is evidence that higher education institutions place a greater emphasis on the volume of graduates than the standard of those who graduate. That may be one of the reasons why today's graduates have in their possession of the title as degree holders' degrees and diplomas, but deficient in necessary skills required for the needs of the current job market. According to Aina \& Casalone (2020), asserted that the current and potential danger in the education of international students is that there is a lack of up-to-date skills, rather than a lack of employment. According to Aina \& Casalone (2020), graduates' training and efficiency and quality are important, and students should really be equipped ideal 
employment that respect their talents, aptitudes, and interests while still financially supporting them.

Studies done by (Mazzarol \& Soutar, 2002) have revealed that international students choose a study destination for higher education based on a number of factors such as the quality of the knowledge acquisition, the availability of networks to gain employment after school, the competence necessary for working environment and many others. Harvey (2001) echoed the banter that is going on among scholars on the benchmarks that determines the employability of graduates after completing school. According to the research by Harvey (2001), many institutions are inclined to cogitate employability an institutional accomplishment instead of the penchant of the individual understudy to get employment, in any case interest in graduate employability has apparently created benefits for all partners including colleges, governments, managers and the actual alumni. In the same vein, Crammer (2006) opined that employability is principally worried about guaranteeing that graduates are fit for adding to financial intensity in a worldwide setting. There are two main kinds of skills required for graduates to achieve employment such as critical subject specific knowledge and skills and transferable knowledge, skills and attitudes (Cox \& King, 2006). Adaptable abilities incorporate oral correspondence, undeniable level mastering abilities, critical thinking, dynamic, and emotional abilities and attributes like obligation, an uplifting outlook, relational abilities and the capacity to work both in a group and freely (Cassidy, 2006). By moving the concentration towards graduate employability as opposed to information obtaining colleges have recognized the need for graduates to build up a scope of individual and scholarly abilities past explicit skill in a scholastic control (Shah et al., 2004) albeit the degree to which this is accomplished at a pragmatic level remaining parts open to discuss.

Current research such as (McQuaid \& Lindsay, 2005) designates that, although universities have a have a task to carry out in supporting employability, employees and employers now see the essential obligation regarding employability resting with the individual for employability resting with the individual As per Fugate et al. (2004), the obligation is on workers to gain information, abilities and capacities, and different attributes esteemed by current and imminent bosses to keep up employability in both current and future business settings. For new graduates, this exchange of obligation implies that businesses are presently searching for individuals who can show a scope of information and abilities applicable to the situation just as versatile practices that will empower them to act in new and regularly complex workplaces (Little, 2001). One path for graduates to exhibit that they have effectively obtained key employability abilities is through giving proof of business related or experiential learning (Hills et al. 2003). In a worldwide climate graduates with global experience would appear to have an employability advantage over those with just neighborhood information. Truth be told, Fugate et al. (2004) contends that it is in the financial, social and social 
interests of countries to guarantee that graduates are satisfactorily set up to work as worldwide residents who are globally sagacious and furnished with the fitting abilities in such manner.

The best combination of soft skills, hard skills, and personality factors improves employability. Each day, the value of soft skills grows in the workplace, and studies show that a shortage of soft skills among graduates is a major challenge for the sector. Soft skills are non-academic skills that can be applied during a career and are a good predictor of employability. While soft skills cannot be associated with employability, they are essential for securing and maintaining jobs at all levels of the organization (Rosenberg, Heimler, \& Morote, 2012). Soft skills are a broad and generalized notion; soft skills have been referred to as people skills, employability skills, emotional skills, and so on (Lavy \& Yadin, 2013). Soft skills cover a wide range of abilities, and many of them are important for professionals and foreign students looking for work in China after completing their education (Pinkowska, Lent, \& Keretho, 2011).

Numerous researchers such as (Colomo-Palacios et al., 2013; Lee \& Lee, 2006) have called attention to the inconsistencies among wanted and had levels of delicate abilities among proficient, and the absence of such abilities in international graduates (Rosenberg et al., 2012). The disparity between delicate expertise arrangement at the scholastic level and industry prerequisites has been alluded to as the expectation gap (Colomo-Palacios et al., 2013). While abilities block by and large vocation advancement of any expert, such insufficiencies then again obstruct new and inventive item improvement in the association and the capacity to rival contenders (Jackson \& Chapman, 2012). At the large-scale level, this disadvantage likewise makes deterrents in the improvement of the whole area. For any expert, expertise hole hampers by and large vocation improvement. Existing writing states that graduates have extensive insufficiencies in self-inspiration and higher request thinking abilities, for example, critical thinking and basic reasoning. Attempting to estimate labor demand and supply for international students and predicting the size and shape of their potential workforce, is no easy job. Educational institutions, employers, and international students will all assume role in developing the employability skills of students. These skills are expected to be offered in the learning environment, and companies and organizations should request unique abilities and expertise in the job market. The literature, on the other hand, showed that there is a disconnect between what education provides and what employers expect in terms of appropriate skills.

Harvey (2005) as supported by Yorke (2004) further revealed the fact that despite the inconsistency and stagnant nature of employment for international students, several universities in developing and developed countries that attract international students are putting in much effort to ensure the employability of international students within an outside country of study. Many businesses have complained that the courses provided by tertiary institutions are too generic or 
vague for their requirements and needs (Quince et al., 2002). Researchers have stated that perhaps the job market's preparation strategy provided by institution for businesses isn't working. This appears to be discrepancies between tertiary institutions and the need of businessmen and women and that only a small amount of attention is given to developing students to meet the needs of business. Tomlinson (2012) asserts that businessmen and women may be due to disagreements among instructional designers about what employment prospects is, how it could be created, and what task universities and colleges should play in its implementation.

International students are far more affected by the following factors when selecting a tertiary institution to attend (Mazzarol \& Soutar, 2002); an university's credibility for quality education, its ties or partnerships with other employers and institutions relevant to the international students, elevated teaching support, strong alumni platforms and recognizable increasing number of international students enrolled at the institution and the recognition of students' achievements and credentials by external bodies. International acceptance of higher education is indeed a thing that impacts overseas students' decisions to study in a foreign country (Maringe \& Carter, 2007). Institutions of higher learning in affluent countries such as the United States, the United Kingdom, Australia, and others have introduced to their education curricula (Clarke, 2018), in all disciplines, a variety of expertise-based learning outcomes that they believe would increase alumni employability (Andrewartha \& Harvey, 2017). For instance, countries in North America, Sin and Amaral (2017) revealed that both the academics and business leaders collaborated to establish employability criteria for their students and also for their international students. Regardless, the breadth of use has not resulted in a standard definition of word. Researchers such as (Fugate \& Kinicki, 2008; Horvath, Goodell, \& Kosteas, 2018; Lowden, Hall, Elliot, \& Lewin, 2011; Su \& Zhang, 2015) echoed that many educational institutions and business stakeholder of countries such as the United Kingdom, United States of America, China and several others have the underlined competencies required for employability. This includes Collaboration, correspondence, administration, basic reasoning, critical thinking, and administrative capacity Critical thinking ability, correspondence and cooperation, self-confidence, activity, and obligation are all on the list in China (Su and Zhang, 2015). The emphasis in the United States is on vocation identity, personal versatility, self-confidence and self-viability, as well as social and human resources.

Research conducted by (Maringe \& Carter, 2007; Chen, 2007) further found that family factors such as inspirations and feedback from family relatives, friends, and loved ones play a significant role regarding the employability decision-making process of international students. Mazzarol and Soutar's (2002) proposed that individual suggestions or informal references of previous graduated class are principal impacts. Despite the fact that an official choice to concentrate abroad is chiefly settled by understudies themselves, their relatives, fam- 
ily members and companions impact them essentially by giving data and idea. Pimpa (2003) demonstrated that the impact of family on the understudies contrasted relying upon the degree of training they wanted to consider. While most of the exploration researched family impact from the two classes of "proposal" and "monetary help", Finance, information, perceptions, competition, and persuasion are among the five categories identified by Pimpa (2003). The strongest factors on international students were financial and aspirations. Furthermore, Mazzarol and Soutar (2002) found that undergraduate students, have a significant parental influence when determining on an international student and their employability. There is limited research conducted to investigate employability of international African students in China. Studies conducted on employability as discussed above considered only students' employability in the international environment but failed to consider the fact that there might be some factors which can influence students assess to employment after school in and outside China.

Endeavors by colleges to expand the employability of their alumni have been censured for a few reasons. In the first place, "employability" depends on abstract impressions framed in a generally short time, instead of on controlled, levelheaded and replicable estimations. As such it is of sketchy unwavering quality and subject to one-sided decisions dependent on sex, race or appearance. Recruiting dependent on "employability", rather than on "objective" measures, for example, scholarly evaluations or work tests, could cover separation (Morley, 2001). Second, a few examinations expect that business is reliant exclusively on characteristics of occupation competitors, on the nature of the inventory of people searching for work. Yet, examines show that the degree of business differs straightforwardly with the interest in laborers, free of the quantity of candidates. At the end of the day, the degree of business relies upon the work to be finished. As a rule, both organic market impact levels of work. Employability ought to, thusly, be perceived not as inserted in an individual but rather as a conditional build. Colleges can influence ( $\mathrm{a}$ few) attributes of the up-and-comers, people can look for specific positions and not others, and bosses can impact qualities of the "request" (work prerequisites) (Clarke, 2018; Tomlinson, 2012). Third, a few specialists question that the colleges are adequately set up to prepare understudies so as to expand their employability. An examination in British colleges of preparing in employability abilities (correspondence, critical thinking, and so on) in five orders (actual sciences and sociologies) revealed that preparation had little impact on graduates' an ideal opportunity to business and situation in graduate-level positions (Cranmer, 2006; Mason, Williams, \& Cranmer, 2009). Real work insight, in any case, builds abilities that expansion employability. Some contend, thusly, that as opposed to "preparing" understudies in employability abilities, colleges ought to give genuine work insight preceding graduation (Cifuentes, Villarroel, \& Geeregat, 2018). Different pundits are worried that the reception of a uniform point of view on abilities needed for work will debilitate 
development and solidify social and monetary imbalances. Internationally, colleges and business are worried about the employability of graduates especially international students. In any case, neither the dependability of its estimation, or legitimacy of its forecast of worker efficiency have yet been authoritatively settled (Suleman, 2018). Numerous inquiries stay unanswered, particularly concerning the preparation and employability of educators. Do the aims and assumptions for college educator coaches match those of the people that will enlist instructor competitors? Is employability a suitable target for instructor preparing? Are the capabilities related with employability liable to improve instructors' ability to empower understudy learning? Are there different variables that impact learning results that are not considered by employability? This paper analyzes the employability of international students and its influencing factors taking into consideration African students (Al Tobi \& Duque, 2015).

Based upon the aforementioned extensive review of related literature, the four main research hypotheses were crafted and derived to govern and guide the study.

Hypothesis One: Personal professional ability has significant effect on international African students' perceived employability in China.

Hypothesis Two: Interpersonal and Communication Ability has significant effect on international African students' perceived employability in China.

Hypothesis Three: University Curriculum and Commitment has significant effect on international African students' perceived employability in China.

Hypothesis Four: Social Support has significant effect on international African students' perceived employability in China.

\section{Material and Methods}

\subsection{Research Design}

The paper adopted the quantitative research approach, specifically using the explanatory research design to examine the perceived employability and influencing factors of international students in China. This research design examines the significant effect among research variables under consideration using quantitative research statistical tools to describe a social phenomenon under consideration. Creswell (2009) opined that explanatory research design defines and document how situations and issues under investigation are and usually includes the evaluation of respondents' behavior, viewpoint regarding other respondents, institutions, practices and procedures and many more. This is also in line with the suggestions of Maigua and Mouni (2016) that the use explanatory designs for research study such as this one allows for the understanding of cause and effect through connecting thoughts. The researcher could describe what was happening as it was, but he or she had no influence over the variables.

\subsection{Population of the Study}

The accessible population of the study therefore comprised all African interna- 
tional students within China. International students pursuing their undergraduate and postgraduates. Studies were involved in the study. Since it was difficult to determine the sample population for all respondents involved in the study, the study relied on recommendations provided by other researchers on the minimum sample size required for quantitative analysis of this kind. Findings of studies such as (Hogarty et al., 2005; MacCallum et al., 2001; Mundfrom et al., 2005; Velicer and Fava, 1998) revealed that the sample size for quantitative analysis is chosen based upon the ratio of variables under investigation and the expected factors. The results of these experiments show that factor solution precision is influenced by the magnitudes of communalities (estimates of reciprocal variance) and factor loadings, sample sizes, and over determination (extent to which each factor is represented by a distinct set of items). McCallum et al., for example, found that wider sample sizes ( $\mathrm{v}$ 14:15), strong communalities ( $\mathrm{v}$ 14:41), and greater over determination ( $\mathrm{v} 14: 11$ ) result in more reliable solutions. Hogarty et al., on the other hand, stressed the role of high communalities and over determination in generating consistency factor solutions. When factor solutions have perfect simple architectures of 1) high factor loadings (e.g., 0.80 and above) or 2) mid-range factor loadings (e.g., $0.40,0.60$ ) with few factors (three or fewer) and large quantities of products, sample sizes of less than 50 may be sufficient (e.g., at least 12 with factor loadings of 0.60 and two factors extracted; de Winter et al., 2009). However, such circumstances are uncommon in nature, necessitating the use of greater sample sizes. Based upon the aforementioned recommendations, 520 African students currently studying in China were chosen for this study.

The background information of respondents has been summarized in Table 1. A total of 514 responses were recovered from the online questionnaire sent across to various international students in China. Six of the responses were deemed incomplete and hence could not be involved in the study. Table 1 revealed the composition of the gender of student's respondents during data collection. Information from Table 1 revealed that $54.3 \%$ of the respondents were males while $45.7 \%$ were female. This signifies that majority of the respondents were males. Table 1 further echoed that (101) representing $19.6 \%$ of the students were pursuing the Bachelor's degrees. A significant number (128) of the respondents were Doctorate degree candidates while (285) 55.4\% were Masters degree candidates. There was a major representation from all the four main dividion of Africa, namely Western Africa (192), Eastern Africa (179), Northern Africa (82) and Southern Africa (61) representing the least representation of $11.9 \%$.

\subsection{Data Collection Instrument}

A standardized questionnaire "Employability Appraisal Scale (EAS)" was adopted for the study to find out how the effect of influencing on the employability on international students in China. The instrument was used to elicit responses 
Table 1. Descriptive statistics.

\begin{tabular}{|c|c|c|}
\hline Variable & Sub-scale & $\begin{array}{c}\text { Frequency } \\
(\%)\end{array}$ \\
\hline \multirow{3}{*}{ Gender } & Male & $279(54.3)$ \\
\hline & Female & $235(45.7)$ \\
\hline & Below 20 & $144(28.0)$ \\
\hline \multirow{3}{*}{ Age (in years) } & $21-26$ & $245(47.7)$ \\
\hline & Above 27 & $125(24.3)$ \\
\hline & Bachelor's degree & $101(19.6)$ \\
\hline \multirow{2}{*}{ Level of Study } & Master's degree & $285(55.4)$ \\
\hline & Doctorate degree & $128(24.9)$ \\
\hline \multirow{6}{*}{ Program of Study } & Business related programs & $87(16.9)$ \\
\hline & Medical sciences related Programs of study & $96(18.7)$ \\
\hline & Material sciences and other sciences related programs & $90(17.5)$ \\
\hline & Engineering related programs & $102(19.8)$ \\
\hline & Computer sciences and related programs & $99(19.3)$ \\
\hline & Mathematics and related programs & $40(7.8)$ \\
\hline \multirow{4}{*}{ Country of Origin } & Western Africa & $192(37.4)$ \\
\hline & Eastern Africa & $179(34.8)$ \\
\hline & Northern Africa & $82(15.9)$ \\
\hline & Sothern Africa & $61(11.9)$ \\
\hline \multirow{4}{*}{ Location of University } & Western zone & $68(13.2)$ \\
\hline & Eastern zone & $122(23.7)$ \\
\hline & Northern zone & $170(33.1)$ \\
\hline & Southern zone & $154(30.0)$ \\
\hline
\end{tabular}

from the international students on their perceptions of the employability skills and competence from past studies such as (Husain, Mokhar, Ahmad, \& Mustapha, 2010; Tsui et al., 1997). Questionnaire was used for the study because it was easy to construct and administered to a large population within a short period of time. Again, researchers decided to use a questionnaire for the study because it is appropriate for survey work and also affords the respondents adequate time to give well thought out answers (Kothari, 2004). The Graduate Employability Appraisal Scale questionnaire is a 50-items measure of graduate students' employability and its influencing factors based on a five-point Likert scale. Respondents indicated their evaluation of graduates' employability and its influencing factors on a scale where ( $1=$ Strongly Disagree and $5=$ Strongly Agree). The questionnaire further collected the demographic information of respondents such as age, gender, academic qualification, course of study, country of origin and place of study in China. Data gotten from the online survey were checked for errors. The 
data will then be coded and entered into the Statistical Product and Services Solution (SPSS) version 25 and afterwards into the AMOS version 22 software. The first section which sought information on demography of respondents will be analyzed using frequencies and percentages. The Structural Equation Model (SEM) was adopted in analyzing the research hypothesis.

\section{Empirical Analysis}

\subsection{Results and Discussion of the Study}

The study made use of Statistical Package for Social Sciences (SPSS version 26) software for both descriptive analysis for respondents and Analysis of Moment (AMOS version 24). A Structural Equation Modeling (SEM) analysis was also performed to evaluate the relationship between the latent and manifest variables presented in our research model. The analysis consists of model parameter fitting indexes, validity and reliability analyses, multicollinearity and autocorrelation analyses, and hypothesis checking. The findings are presented in the following sections.

The study tested all preliminary assumptions that are supposed to be met before descriptive and inferential statistics is conducted such as validity, reliability, normality test, multicollinearity and auto-correlation analysis. The validity and reliability of the individual test items were analyzed for reliability using the Cronbach alpha reliability coefficient value. For each and every construct (factors) that were considered to have an influence on students' perceived employability, reliability was checked.

\subsection{Diagnostic Test of Autocorrelation and Multicollinearity}

The study measured multicollinearity to find out whether there is or not high correlations between two or more predictor variables. Using the Tolerance value, Variance-Inflation-Factor (VIF) and the coefficient of correlation, the autocorrelation and multicollinearity were estimated to measure the extent which items in a questionnaire measure the same construct. Recommendations from Yoo et al., (2014) echoed that multicollinearity exist if the correlation coefficient greater than $0.80(\rho>0.80$. The A tolerance value and VIF all indicated there was no presence autocorrelation and multicollinearity. Table 2 indicates that, the desired

Table 2. Correlation matrix.

\begin{tabular}{|c|c|c|c|c|c|c|c|c|c|c|}
\hline \multirow{2}{*}{ Variable } & \multirow{2}{*}{ Mean } & \multirow{2}{*}{$\begin{array}{l}\text { Std. } \\
\text { Dev }\end{array}$} & \multicolumn{5}{|c|}{ Correlation matrix } & \multirow{2}{*}{ Tolerance } & \multirow{2}{*}{ VIF } & \multirow{2}{*}{ Durbin-Watson } \\
\hline & & & 1 & 2 & 3 & 4 & 5 & & & \\
\hline PEM & 16.63 & 7.653 & 0.845 & & & & & & & \\
\hline PP & 48.11 & 6.789 & $0.718^{\star *}$ & 0.845 & & & & 0.578 & 2.012 & \\
\hline ICA & 27.33 & 10.668 & $0.657^{\star *}$ & $0.650^{\star *}$ & 0.844 & & & 0.575 & 2.122 & 2.302 \\
\hline UCC & 31.39 & 6.526 & $0.655^{\star *}$ & $0.344^{\star \star}$ & $0.572^{\star *}$ & 0.857 & & 0.581 & 2.569 & \\
\hline SS & 189.34 & 31.096 & $0.604^{\star *}$ & $0.187^{\star \star}$ & $0.174^{\star \star} 0$ & $0.356^{\star *}$ & 0.851 & 0.588 & 2.541 & \\
\hline
\end{tabular}

${ }^{*}$ Correlation is significant at the 0.01 (2-tailed); diagonals: square root of AVEs. 
estimates for Tolerance, VIF and Durbin-Watson were all achieved, further indicating no multicollinearity and autocorrelation in our dataset.

\subsection{Construct Validity and Reliability}

As requirement for estimating Structural Equation Modeling, Construct validity (Convergent validity and Discriminant validity) of our structural model was examined using by using Composite Reliability index (CR) and Average Variance Extracted (AVE) (Bagozzi et al., 1998; Fornell \& Lacker, 1981). In line with findings of studies aforesaid, a minimum AVE value of 0.50 is required to achieve convergent validity, hence the dataset was deemed appropriated since the AVEs of all the construct is greater than 0.50 value. Regarding the Discriminant validity, studies by Fornell and Lacker (1981) echoed that if the square root of the AVE of each latent construct is greater than the correlation coefficients between that latent construct and other latent constructs, then discriminant validity criterion is satisfied. Result in Table 3 indicates that the square root of the AVE for each of the latent construct is greater than the inter-correlations between the latent constructs. Therefore, discriminant validity was also achieved.

The study also measured the reliability of the model using Cronbach's alpha and Composite reliability. Adopting suggestions from (DeVon et al., 2007; Fornell \& Lacker, 1981), minimum Composite reliability value of 0.60 and Bland \& Altman (1997) recommended a minimum Cronbach's value of 0.70 for good or acceptable reliabilities. The results of Table 4 the estimated Cronbach's alpha and Composite reliability values are above the minimum threshold to achieve construct reliability; therefore, the reliability of our constructs was achieved.

$$
\mathrm{AVE}=\Sigma K^{2} / n ; \quad \mathrm{CR}=(\Sigma K)^{2} /\left[(\Sigma K)^{2}+\left(\Sigma 1-K^{2}\right)\right]
$$

where $K=$ factor loadings of all items per construct; $n=$ number of items per construct.

Table 3 postulates the results for the structural model. Information from $\mathrm{Ta}$ ble 3 revealed that all standardized factor loadings are all statistically significant with $(p<0.05)$ and T-values greater than $1.96\left(\mathrm{t}_{\text {cal }}>\mathrm{t}_{\text {critical }}\right)$. This is in line with recommendations by (Chin et al., 1997; Field, 2009; Hair et al., 2006) that factor loadings are considered satisfactory to estimating relationship between independent and dependents with latent and manifest constructs. The Standardized factor loadings illustrated in Table 4 are exceeds the minimum threshold recommended for conducting such analysis.

The fitness of the model fitness was tested and checked using Chi-square ratio ( $\chi^{2}$-ratio), Root Mean Square Error of Approximation (RMSEA), Comparative Fit Index (CFI), Tucker-Lewis Index (TLI), Goodness of Fit Index (GFI), Normed Fit Index (NFI) and Standardized Root Mean Square Residual (SRMR). The model fitness can be described as the extent to which Structural Equation 
Table 3. Results of structural model.

\begin{tabular}{|c|c|c|c|c|c|c|c|}
\hline $\begin{array}{c}\text { Latent } \\
\text { Variable }\end{array}$ & Items & $\begin{array}{l}\text { Standardized } \\
\text { loading }\end{array}$ & $t$-value & $p$-value & AVE & CR & $\begin{array}{c}\text { Cronbach's } \\
\text { Alpha }\end{array}$ \\
\hline \multirow{4}{*}{ PP } & PP1 & 0.74 & 7.23 & $* * *$ & \multirow{4}{*}{0.714} & \multirow{4}{*}{0.909} & \multirow{4}{*}{0.783} \\
\hline & PP2 & 0.86 & 7.25 & $* * *$ & & & \\
\hline & PP3 & 0.83 & $\mathrm{a}$ & a & & & \\
\hline & PP4 & 0.94 & 8.31 & $* * *$ & & & \\
\hline \multirow{11}{*}{ ICA } & IC5 & 0.86 & 8.15 & $* * *$ & \multirow{11}{*}{0.715} & & \multirow{11}{*}{0.899} \\
\hline & IC6 & 0.89 & 8.22 & $* * *$ & & & \\
\hline & IC7 & 0.76 & 7.56 & $* * *$ & & & \\
\hline & IC8 & 0.84 & 7.89 & $* * *$ & & & \\
\hline & IC9 & 0.77 & 7.91 & $* * *$ & & & \\
\hline & IC10 & 0.91 & 7.88 & $* * *$ & & & \\
\hline & IC11 & 0.81 & 7.59 & $* * *$ & & & \\
\hline & IC12 & 0.82 & a & a & & 0.965 & \\
\hline & IC13 & 0.87 & 7.28 & $* * *$ & & & \\
\hline & IC14 & 0.89 & 7.34 & $* * *$ & & & \\
\hline & IC15 & 0.87 & 8.12 & $* * *$ & & & \\
\hline \multirow{8}{*}{ UCC } & UC16 & 0.89 & 7.34 & $* * *$ & \multirow{8}{*}{0.714} & \multirow{8}{*}{0.952} & \multirow{8}{*}{0.958} \\
\hline & UC17 & 0.76 & 7.17 & $* * *$ & & & \\
\hline & UC18 & 0.87 & 7.28 & $* * *$ & & & \\
\hline & UC19 & 0.87 & 7.18 & $* * *$ & & & \\
\hline & UC20 & 0.89 & a & $\mathrm{a}$ & & & \\
\hline & UC21 & 0.85 & 7.36 & $* * *$ & & & \\
\hline & UC22 & 0.78 & 7.28 & $* * *$ & & & \\
\hline & UC23 & 0.84 & 7.24 & $* * *$ & & & \\
\hline \multirow{7}{*}{ SS } & SS24 & 0.83 & 7.28 & $* * *$ & \multirow{7}{*}{0.736} & \multirow{7}{*}{0.951} & \multirow{7}{*}{0.786} \\
\hline & SS25 & 0.82 & 7.81 & $* * *$ & & & \\
\hline & SS26 & 0.87 & 7.44 & $* * *$ & & & \\
\hline & SS27 & 0.88 & $\mathrm{a}$ & a & & & \\
\hline & SS28 & 0.88 & 7.42 & $* * *$ & & & \\
\hline & SS29 & 0.81 & 7.72 & $* * *$ & & & \\
\hline & SS30 & 0.91 & 7.61 & $* * *$ & & & \\
\hline \multirow{5}{*}{ PEM } & PE31 & 0.89 & 8.07 & $* * *$ & & & \\
\hline & PE32 & 0.86 & 7.71 & $* * *$ & & & \\
\hline & PE33 & 0.83 & 7.89 & $* * *$ & & & \\
\hline & PE34 & 0.81 & 7.32 & $* * *$ & & & \\
\hline & PE35 & 0.87 & 7.65 & $* * *$ & & & \\
\hline
\end{tabular}




\begin{tabular}{ccccccc}
\hline PE36 & 0.85 & 7.43 & $* * *$ & & & \\
PE37 & 0.87 & a & a & 0.725 & 0.971 & 0.889 \\
PE38 & 0.88 & 7.88 & $* * *$ & & & \\
PE39 & 0.81 & 8.18 & $* * *$ & & & \\
PE40 & 0.79 & 7.23 & $* * *$ & & \\
PE41 & 0.83 & 7.28 & $* * *$ & & \\
PE42 & 0.89 & 7.21 & $* * *$ & & \\
PE43 & 0.88 & 7.18 & $* * *$ & & \\
\hline
\end{tabular}

${ }^{* * *} p$-value $<0.001$ (2-tailed), a: Unitized parameter.

Table 4. Fitting indices.

\begin{tabular}{cccccccc}
\hline \multirow{2}{*}{ Fitting Index } & \multicolumn{7}{c}{ Fitting Parameters } \\
\cline { 2 - 8 } & $\mathbf{x} / \mathrm{df}$ & RMSEA & CFI & TLI & GFI & NFI & SRMR \\
\hline Fitting Indices & 1.421 & 0.042 & 0.919 & 0.962 & 0.945 & 0.955 & 0.043 \\
\hline
\end{tabular}

Modeling bouts the data observed. As reported by Kline (2005) that in ascertaining model fitness, the following indices were deemed appropriate, hence $\chi^{2}$, RMSEA, CFI, SRMR in reporting the results for structural equation model. Regarding a Chi-square ratio ( $\chi^{2}$-ratio), a model is deemed fit and acceptable if $\chi^{2}$ is less than 3 (Bwaliez \& Abushaikha, 2019). Also, the TLI should be TLI $>0.90$ for a model to be deemed fit and acceptable (Burnham \& Anderson, 2002; Kline, 2005). They further recommended that RMSEA and SRMR are also recommended to be less than 0.05 (RMSEA, SRMR $<0.05$ ) for a satisfactory model fit and less than 0.08 (RMSEA, SRMR < 0.08) for an acceptable model fit. GFI and NFI are mandated to be greater than 0.95 (GFI, NFI $>0.95$ ) for a satisfactory model fit. All the fitness indices required to be tested and achieved were attained by the model as summarized in Table 4 .

\subsection{Hypothesis Testing}

The four hypotheses were tested and analyzed using structural equation modelling to establish statistical significance at $95 \%$ confidence interval. The outcome in Table 5 summarizes the findings of the study regarding how influencing factors such as personal professional ability, interpersonal and communication ability, University Curriculum and Commitment and Social Support influences international African students' perceived employability in China.

Theorem 1: $H_{i}$ : Personal professional ability has significant effect on international African students' perceived employability in China.

Proof of Theorem 1: Information from Table 5 revealed a significant positive effect of African international students in China personal professional ability on perceived employability. This was reflected in the coefficient $\left(\left(\beta_{1}=0.84, p<\right.\right.$ 
Table 5. Hypothesis testing and decision.

\begin{tabular}{ccccccc}
\hline Hypothesis & Relationship & $\begin{array}{c}\text { Path } \\
\text { coefficient }\end{array}$ & SE & t-value & Sig-value & $\begin{array}{c}\text { Hypothesis } \\
\text { Decision }\end{array}$ \\
\hline H1 & PP $\rightarrow$ PEM & 0.84 & 0.18 & 19.805 & $* * *$ & Accepted \\
H3 & ICA $\rightarrow$ PEM & 0.72 & 0.39 & 4.608 & $* * *$ & Accepted \\
H3 & UCC $\rightarrow$ PEM & 0.74 & 0.21 & 12.273 & $* * *$ & Accepted \\
H4 & SS $\rightarrow$ PEM & 0.68 & 0.21 & 20.617 & $* * *$ & Accepted \\
\hline
\end{tabular}

${ }^{* * *}$ Statistically significance at the 0.05 level $(p<0.05)$.

0.001) which suggest that an increase in students' personal professional ability such as the possession of basic soft, technical and digital skills as knowledge of e-commerce, internet and software knowledge would increase their perceived employability and that a $1 \%$ increase in personal professional ability would increase and boost Africa students' employability by the coefficient $(0.84)$. The researcher accepted this decision and also tested the other hypothesis to determine the degree of relationship that exist between other variables.

Theorem 2: $H_{2}$ : Interpersonal and Communication Ability has significant effect on international African students' perceived employability in China

Proof of Theorem 2: The second research hypothesis was also tested using the SEM path analysis. Table indicates that interpersonal and communication ability has a significant positive relationship to perceived employability in China. Table 5 shows that that hypothesis has been accepted from the study's analysis $\left(\beta_{2}=0.72\right.$ and $\left.p<0.001\right)$. For instance, the interpersonal and communication ability of international students such as willingness of students to learn new things, take on responsibility, self-motivation, skill of problem solving, good verbal skill and human skills positively influences their perceived employability by (0.72). This implies that $1 \%$ increase in interpersonal and communication of African students studying in China would cause a significant increment in the likelihood of perceived employability within and outside of China.

Theorem 3: $\mathrm{H}_{3}$ University Curriculum and Commitment has significant effect on international African students perceived employability in China

Proof of Theorem 3: Table 5 reported the relationship between dependent and independents variables in the third research hypothesis From Table 5, it was found that was a positive statistically significant influence of university curriculum and commitment of students' perceived employability of international students in China, especially African students. This was amply reflected in the coeffiffifficient $\left(\beta_{3}=0.74, p<0.01\right)$ showing that university curriculum and commitment such as university's connections, how it cares about its students after completion, offering courses that can attract businessmen and women to employ students' services after school, inspiring and challenging to be the best student significantly influences international African students' perceived employability. This signifies that the university that international students attend in China has a greater chance of determining students access to employment after school or 
not. Also, the role that the university play in making sure that student interpersonal, personal professional ability are developed all play a role in international students' employability.

Theorem 4: $H_{4}$ Social Support has significant effect on international African students' perceived employability in China

Proof of Theorem 4: The final hypothesis was accepted by the researchers after testing its level of significance and path towards establishing a positive relationship between Social Support and perceived employability in China. Table 5 further revealed that a significant positive relationship exists between social support provided by international students' family, friends and love ones and their perceived employability. The researchers found social support significantly and positively influence perceived employability in China. And that a $1 \%$ increase in social support would significantly increase perceived employability by the coefficient $\left(\beta_{3}=0.68, p<0.01\right)$. Social support of international students such as the willingness of family to provide support in looking for employment after school; counting of friends for job, and the ability of friends, family and love ones to provide emotional support can significantly influence international students' employability in a positive direction.

The overall findings of the study are in line with findings of other researchers who investigated the same phenomenon under different research methodology, setting and many more. For instance, the findings of the study confirm the findings of (Al Tobi \& Duque, 2015; Andrewartha \& Harvey, 2017; Chen, 2007; Cifuentes, Villarroel, and Geeregat, 2018; Clarke, 2018; Colomo-Palacios et al., 2013; Fugate \& Kinicki, 2008; Harvey, 2005; Horvath, Goodell, \& Kosteas, 2018; Lowden, Hall, Elliot, \& Lewin, 2011; Maringe \& Carter, 2007; Pimpa, 2003; Rosenberg et al., 2012; Su \& Zhang, 2015; Suleman, 2018; Tomlinson, 2012). The findings of the aforementioned study confirmed that factors such as the personal professional ability, interpersonal communication ability, university curriculum and social support from friends, family and loves one influences employability of graduates.

\section{Conclusion and Limitations}

The study focused on how influencing factors such as Personal ability, social support, university curriculum and commitment and interpersonal and communication abilities influences international students in China employability. Using the multiple regression analysis, the study concluded that there is a significant positive relationship and impact of influencing factors aforesaid on international students' perceived employability. Based upon the findings of the study, it can be concluded that international students should attach seriousness to acquiring adequate knowledge in basic soft skills such as teamwork, flexibility, technical skills and use of modern technology in their respective course of study. It can be assumed that students who acquire adequate knowledge in creative thinking, attention to details to area of study are likely to get employment within 
China or outside China. Hence, international students are to take their personal professional ability seriously so as to get employment. The study further found that interpersonal communication significantly and positively influences international students perceived employability. This implies that international African students studying in China should take the opportunity to learn interpersonal skills such as ability to work in team and be open minded to learn from people as they become self-motivated and committed in problem solving, ability to cope with stress, work independently and good communication skills. All of these skills in the long run will be required of them should they get employed.

University Curriculum and Commitment and social support also had a significant positive effect of students' perceived employability. This implies that factors which are outside the ability of students also influence students perceived employability. The kind of university attended also influences their chances of getting employed after school. The curriculum designed for students, university's connections to business stakeholders or stakeholder of the job market can also pose as a benefit to students in getting employment after schools. The higher the connections of the lecturers, university staffs in connecting students to job market, the greater students' chances of getting employed. Again, social support in their form of parent's financial support and social networks of students themselves can serve a great opportunity for students' employability. There is a need for students as international students to create networks with their fellow international students, lecturers and many more so that they can utilize those networks towards getting employment.

The study concentrated on only African students who are currently studying in China; hence, the findings of the study can only be generalized to African students in China. In future studies, there will be a need to involved other countries from the developed and developing countries currently in China for studies to also have a better understanding of how the think influencing factors such as personal professional ability, interpersonal and communication ability, University Curriculum and Commitment and Social Support influence students perceived employability within and outside China.

\section{Conflicts of Interest}

The authors declare that there is no conflict of interest in conducting this research.

\section{References}

Abas, M. C., \& Imam, O. A. (2016). Graduates' Competence on Employability Skills and Job Performance. International Journal of Evaluation and Research in Education, 5, 119-125. https://doi.org/10.11591/ijere.v5i2.4530

Abas-Mastura, M., Imam, O. A., \& Osman, S. (2013). Employability Skills and Task Performance of Employees in Government Sector. International Journal of Humanities and Social Science, 3, 150-162.

Aina, C., \& Casalone, G. (2020). Early Labor Market Outcomes of University Graduates: 
Does Time to Degree Matter? Socio-Economic Planning Sciences, 71, Article ID: 100822. https://doi.org/10.1016/j.seps.2020.100822

Al Tobi, A. S., \& Duque, S. (2015). Approaches to Quality Assurance and Accreditation in Higher Education: A Comparison between the Sultanate of Oman and the Philippines. Perspectives of Innovations, Economics and Business, 15, 41-49. https://doi.org/10.15208/pieb.2015.03

Andrewartha, L., \& Harvey, A. (2017). Employability and Student Equity in Higher Education: The Role of University Careers Services. Australian Journal of Career Development, 26, 71-80. https://doi.org/10.1177/1038416217718365

Bagozzi, R. P., Yi, Y., \&Nassen, K. D. (1998). Representation of Measurement Error in Marketing Variables: Review of Approaches and Extension to Three-Facet Designs. Journal of Econometrics, 89, 393-421. https://doi.org/10.1016/S0304-4076(98)00068-2

Bland, J. M., \& Altman, D. G. (1997). Statistics Notes: Cronbach’s Alpha. BMJ, 314, 572. https://doi.org/10.1136/bmj.314.7080.572

Burnham, K. P., \& Anderson, D. R. (2002). A Practical Information-Theoretic Approach. Model Selection and Multimodel Inference, 2, 70-71.

Bwaliez, O. M., \&Abushaikha, I. (2019). Integrating the SRM and Lean Paradigms: The Constructs and Measurements. Theoretical Economics Letters, 9, 2371. https://doi.org/10.4236/tel.2019.97151

Camiciottoli, B. C. (2010). Meeting the Challenges of European Student Mobility: Preparing Italian Erasmus Students for Business Lectures in English. English for Specific Purposes, 29, 268-280. https://doi.org/10.1016/j.esp.2010.01.001

Cassidy, S. (2006). Developing Employability Skills: Peer Assessment in Higher Education. Education+ Training, 48, 508-517. https://doi.org/10.1108/00400910610705890

Chen, Y. (2017). Graduate Employability: The Perspective of Social Network Learning. EURASIA Journal of Mathematics, Science and Technology Education, 13, 2567-2580. https://doi.org/10.12973/eurasia.2017.01241a

China Power Team (2017). Is China Both a Source and Hub for International Students? China Power. https://chinapower.csis.org/china-international-students

Cifuentes, G., Villarroel, M., \& Geeregat, O. (2018). Influye la universidad en la empleabilidad exitosa de los titulados de pedagogía? Estudios Pedagógicos, 44, 207-224. https://doi.org/10.4067/S0718-07052018000100207

Clarke, M. (2018). Rethinking Graduate Employability: The Role of Capital, Individual Attributes and Context. Studies in Higher Education, 43, 1923-1937. https://doi.org/10.1080/03075079.2017.1294152

Colomo-Palacios, R., Casado-Lumbreras, C., Soto-Acosta, P., García-Peñalvo, F. J., \& Tovar-Caro, E. (2013). Competence Gaps in Software Personnel: A Multi-Organizational Study. Computers in Human Behavior, 29, 456-461. https://doi.org/10.1016/j.chb.2012.04.021

Cox, S., \& King, D. (2006). Skill Sets: An Approach to Embed Employability in Course Design. Education+ Training, 48, 262-274. https://doi.org/10.1108/00400910610671933

Cranmer, S. (2006). Enhancing Graduate Employability: Best Intentions and Mixed Outcomes. Studies in Higher Education, 31, 169-184.

https://doi.org/10.1080/03075070600572041

Creswell, J. W. (2009). Mapping the Field of Mixed Methods Research. Journal of Mixed Methods Research, 3, 95-108. https://doi.org/10.1177/1558689808330883

Dams, A. E., \& Pagola, H. A. (2007). Exchange Students Experience at the Buenos Aires 
University, School of Engineering. 2007 37th Annual Frontiers in Education Conference-Global Engineering: Knowledge without Borders, Opportunities without Passports, Milwaukee, 10-13 October 2007, T2A-6. https://doi.org/10.1109/FIE.2007.4417961

David-West, A., \& Choi, K. (2010). Teaching English to North Korean Refugees in South Korea: An Interview with Karen Choi. North Korean Review, 6, 108-119. https://doi.org/10.3172/NKR.6.1.108

de Winter, J. C., Dodou, D. I. M. I. T. R. A., \& Wieringa, P. A. (2009). Exploratory Factor Analysis with Small Sample Sizes. Multivariate Behavioral Research, 44, 147-181. https://doi.org/10.1080/00273170902794206

DeVon, H. A., Block, M. E., Moyle-Wright, P., Ernst, D. M., Hayden, S. J., Lazzara, D. J., Kostas-Polston, E. et al. (2007). A Psychometric Toolbox for Testing Validity and Reliability. Journal of Nursing Scholarship, 39, 155-164. https://doi.org/10.1111/j.1547-5069.2007.00161.x

Donald, W. E., Baruch, Y., \& Ashleigh, M. (2019). The Undergraduate Self-Perception of Employability: Human Capital, Careers Advice, and Career Ownership. Studies in Higher Education, 44, 599-614. https://doi.org/10.1080/03075079.2017.1387107

Dorozhkin, I. N., \& Mazitova, L. T. (2008). Problems of the Social Adaptation of Foreign College Students. Russian Education \& Society, 50, 23-30. https://doi.org/10.2753/RES1060-9393500202

Fallows, S., \& Steven, C. (2000). Building Employability Skills into the Higher Education Curriculum: A University-Wide Initiative. Education + Training, 42, 75-82. https://doi.org/10.1108/00400910010331620

Fornell, C., \&Larcker, D. F. (1981). Evaluating Structural Equation Models with Unobservable Variables and Measurement Error. Journal of Marketing Research, 18, 39-50. https://doi.org/10.1177/002224378101800104

Forrier, A., \& Sels, L. (2003). Temporary Employment and Employability: Training Opportunities and Efforts of Temporary and Permanent Employees in Belgium. Work, Employment and Society, 17, 641-666. https://doi.org/10.1177/0950017003174003

Fugate, M., \& Kinicki, A. J. (2008). A Dispositional Approach to Employability: Development of a Measure and Test of Implications for Employee Reactions to Organizational Change. Journal of Occupational and Organizational Psychology, 81, 503-527. https://doi.org/10.1348/096317907X241579

Fugate, M., Kinicki, A. J., \& Ashforth, B. E. (2004). Employability: A Psycho-Social Construct, Its Dimensions, and Applications. Journal of Vocational behavior, 65, 14-38. https://doi.org/10.1016/j.jvb.2003.10.005

Green, A. E. (2003). Labour Market Trends, Skill Needs and the Ageing of the Workforce: A Challenge for Employability? Local Economy, 18, 306-321. https://doi.org/10.1080/0269094032000153835

Guo, S., \& Guo, Y. (2016). Spotlight on China: Changes in Education under China's Market Economy. Springer. https://doi.org/10.1007/978-94-6209-881-7

Harvey, L. (2001). Defining and Measuring Employability. Quality in Higher Education, 7, 97-109. https://doi.org/10.1080/13538320120059990

Harvey, L. (2005). Embedding and Integrating Employability. New Directions for Institutional Research, 128, 13-28. https://doi.org/10.1002/ir.160

Hills, J. M., Robertson, G., Walker, R., Adey, M. A., \& Nixon, I. (2003). Bridging the Gap between Degree Programme Curricula and Employability through Implementation of Work-Related Learning. Teaching in Higher Education, 8, 211-231. 


\section{https://doi.org/10.1080/1356251032000052456}

Hogarty, K. Y., Hines, C. V., Kromrey, J. D., Ferron, J. M., \& Mumford, K. R. (2005). The Quality of Factor Solutions in Exploratory Factor Analysis: The Influence of Sample Size, Communality, and Overdetermination. Educational and Psychological Measurement, 65, 202-226. https://doi.org/10.1177/0013164404267287

Holmes, L. (2013). Competing Perspectives on Graduate Employability: Possession, Position or Process? Studies in Higher Education, 38, 538-554.

https://doi.org/10.1080/03075079.2011.587140

Horvath, M., Goodell, J. E., \& Kosteas, V. D. (2018). Decisions to Enter and Continue in the Teaching Profession: Evidence from a Sample of US Secondary STEM Teacher Candidates. Teaching and Teacher Education, 71, 57-65.

https://doi.org/10.1016/j.tate.2017.12.007

Husain, M. Y., Mokhtar, S. B., Ahmad, A. A., \& Mustapha, R. (2010). Importance of Employability Skills from Employers' Perspective. Procedia-Social and Behavioral Sciences, 7, 430-438. https://doi.org/10.1016/j.sbspro.2010.10.059

Jackson, D., \& Chapman, E. (2012). Non-Technical Skill Gaps in Australian Business Graduates. Education+ Training, 54, 95-113. https://doi.org/10.1108/00400911211210224

Ju, S., Zhang, D., \& Pacha, J. (2012). Employability Skills Valued by Employers as Important for Entry-Level Employees with and without Disabilities. Career Development and Transition for Exceptional Individuals, 35, 29-38.

https://doi.org/10.1177/0885728811419167

King, R., Findlay, A. M., \& Ahrens, J. (2010). International Student Mobility Literature Review. HEFCE.

King, R., Findlay, A., Ahrens, J., \& Dunne, M. (2011). Reproducing Advantage: The Perspective of English School Leavers on Studying Abroad. Globalisation, Societies and Education, 9, 161-181. https://doi.org/10.1080/14767724.2011.577307

Kline, T. (2005). Psychological Testing: A Practical Approach to Design and Evaluation. Sage. https://doi.org/10.4135/9781483385693

Kothari, C. R. (2004). Research Methodology: Methods and Techniques. New Age International Publishers.

Lavy, I., \& Yadin, A. (2013). Soft Skills-An Important Key for Employability in the "Shift to a Service Driven Economy" Era. International Journal of e-Education, eBusiness, e-Management and e-Learning, 3, 416. https://doi.org/10.7763/IJEEEE.2013.V3.270

Lee, S. M., \& Lee, C. K. (2006). IT Managers' Requisite Skills. Communications of the ACM, 49, 111-114. https://doi.org/10.1145/1121949.1121974

Lindberg, M. E. (2007). At the Frontier of Graduate Surveys. Higher Education, 53, 623-644. https://doi.org/10.1007/s10734-005-1672-4

Little, B. (2001). Reading between the Lines of Graduate Employment. Quality in Higher Education, 7, 121-129. https://doi.org/10.1080/13538320120060015

Lowden, K., Hall, S., Elliot, D., \& Lewin, J. (2011). Employers' Perceptions of the Employability Skills of New Graduates. Edge Foundation.

MacCallum, R. C., Widaman, K. F., Preacher, K. J., \& Hong, S. (2001). Sample Size in Factor Analysis: The Role of Model Error. Multivariate Behavioral Research, 36, 611-637. https://doi.org/10.1207/S15327906MBR3604 06

Maigua, C., \& Mouni, G. (2016). Influence of Interest Rates Determinants on the Perfor- 
mance of Commercial Banks in Kenya. International Journal of Academic Research in Accounting, Finance and Management Sciences, 6, 121-133. https://doi.org/10.6007/IJARAFMS/v6-i2/2078

Maringe, F., \& Carter, S. (2007). International Students' Motivations for Studying in UK HE: Insights into the Choice and Decision Making of African Students. International Journal of Educational Management, 21, 459-475. https://doi.org/10.1108/09513540710780000

Mason, G., Williams, G., \& Cranmer, S. (2009). Employability Skills Initiatives in Higher Education: What Effects Do They Have on Graduate Labour Market Outcomes? Education Economics, 17, 1-30. https://doi.org/10.1080/09645290802028315

Mazzarol, T., \& Soutar, G. N. (2002). “Push-Pull” Factors Influencing International Student Destination Choice. International Journal of Educational Management, 16, 82-90. https://doi.org/10.1108/09513540210418403

McQuaid, R. W., \& Lindsay, C. (2005). The Concept of Employability. Urban Studies, 42, 197-219. https://doi.org/10.1080/0042098042000316100

Morley, L. (2001). Producing New Workers: Quality, Equality and Employability in Higher Education. Quality in Higher Education, 7, 131-138.

https://doi.org/10.1080/13538320120060024

Mundfrom, D. J., Shaw, D. G., \& Ke, T. L. (2005). Minimum Sample Size Recommendations for Conducting Factor Analyses. International Journal of Testing, 5, 159-168. https://doi.org/10.1207/s15327574ijt0502 4

Ngwira, F., Mapoma, H., Hong, J., Sariyo, S., \& Kondowe, W. (2015). Intercultural Communication Competence and Acculturation among International Students in Central China. Intercultural Communication Studies, 24, 61.

https://www.semanticscholar.org/paper/Intercultural-Communication-Competence-an damong-in-Ngwira Mapoma/c45ff6e48d1103a867c63965a6fd900909ef02a5

Pimpa, N. (2003). The Influence of Family on Thai Students' Choices of International Education. International Journal of Educational Management, 17, 211-219. https://doi.org/10.1108/09513540310484931

Pinkowska, M., Lent, B., \& Keretho, S. (2011). Process Based Identification of Software Project Manager Soft Skills. 2011 Eighth International Joint Conference on Computer Science and Software Engineering (JCSSE), Nakhonpathom, 11-13 May 2011, 343-348. https://doi.org/10.1109/JCSSE.2011.5930145

Quince, T., Whittaker, H., \& Enterprises, M. S. (2002). High Tech Businesses in the UK: Performance and Niche Markets. University of Cambridge, ESRC Centre for Business Research.

Rosenberg, S., Heimler, R., \& Morote, E. S. (2012). Basic Employability Skills: A Triangular Design Approach. Education+ Training, 54, 7-20. https://doi.org/10.1108/00400911211198869

Rothwell, A., \& Arnold, J. (2007). Self-Perceived Employability: Development and Validation of a Scale. Personnel Review, 36, 23-41. https://doi.org/10.1108/00483480710716704

Sciolla, A., Ziajko, L. A., \& Salguero, M. L. (2010). Sexual Health Competence of International Medical Graduate Psychiatric Residents in the United States. Academic Psychiatry, 34, 361-368. https://doi.org/10.1176/appi.ap.34.5.361

Shafie, L. A., \& Nayan, S. (2010). Employability Awareness among Malaysian Undergraduates. International Journal of Business and Management, 5, 119.

https://doi.org/10.5539/ijbm.v5n8p119 
Shah, A., Pell, K., \& Brooke, P. (2004). Beyond First Destinations: Graduate Employability Survey. Active Learning in Higher Education, 5, 9-26. https://doi.org/10.1177/1469787404040457

Sin, C., \& Amaral, A. (2017). Academics and Employers' Perceptions about Responsibilities for Employability and Their Initiatives towards Its Development. Higher Education, 73, 97-111. https://doi.org/10.1007/s10734-016-0007-y

Su, W., \& Zhang, M. (2015). An Integrative Model for Measuring Graduates' Employability Skills-A Study in China. Cogent Business \& Management, 2, Article ID: 1060729. https://doi.org/10.1080/23311975.2015.1060729

Suleman, F. (2018). The Employability Skills of Higher Education Graduates: Insights into Conceptual Frameworks and Methodological Options. Higher Education, 76, 263-278. https://doi.org/10.1007/s10734-017-0207-0

Thijssen, J. G., Van der Heijden, B. I., \& Rocco, T. S. (2008). Toward the Employability_Link Model: Current Employment Transition to Future Employment Perspectives. Human Resource Development Review, 7, 165-183. https://doi.org/10.1177/1534484308314955

Tomlinson, M. (2007). Graduate Employability and Student Attitudes and Orientations to the Labour Market. Journal of Education and Work, 20, 285-304. https://doi.org/10.1080/13639080701650164

Tomlinson, M. (2012). Graduate Employability: A Review of Conceptual and Empirical Themes. Higher Education Policy, 25, 407-431. https://doi.org/10.1057/hep.2011.26

Tsui, A. S., Pearce, J. L., Porter, L. W., \& Tripoli, A. M. (1997). Alternative Approaches to the Employee-Organization Relationship: Does Investment in Employees Pay off? Alternative Applied Science and Technology, 40, 1089-1121.

Velicer, W. F., \& Fava, J. L. (1998). Effects of Variable and Subject Sampling on Factor Pattern Recovery. Psychological Methods, 3, 231.

https://doi.org/10.1037/1082-989X.3.2.231

Waters, J. L. (2009). In Pursuit of Scarcity: Transnational Students, "Employability”, and the MBA. Environment and Planning A, 41, 1865-1883. https://doi.org/10.1068/a40319

Wilton, N. (2008). Do Employability Skills Really Matter in the UK Graduate Labour Market? The Case of Business and Management Graduates. Work Employment \& Society, 25, 85-100.

Yoo, W., Mayberry, R., Bae, S., Singh, K., He, Q. P., \&Lillard Jr., J. W. (2014). A Study of Effects of Multicollinearity in the Multivariable Analysis. International Journal of Applied Science and Technology, 4, 9-19.

Yorke, M. (2004). Employability in the Undergraduate Curriculum: Some Student Perspectives. European Journal of Education, 39, 409-427.

https://doi.org/10.1111/j.1465-3435.2004.00194.x 